\title{
Evaluation of thiol-disulphide homeostasis in patients with chronic hepatitis B
}

\section{Kronik hepatit B hastalarında tiyol-disülfid hemostazının değerlendirilmesi}

\author{
Fikriye Milletli-Sezgin ${ }^{1 *}$ (D), Rukiye Nar ${ }^{2}$ (D), Lokman Hızmalı ${ }^{3}$ \\ ${ }^{1}$ Department of Medical Microbiology, Ahi Evran University School of Medicine, Kirsehir, Turkey \\ ${ }^{2}$ Department of Medical Biochemistry, Pamukkale University School of Medicine, Denizli, Turkey \\ ${ }^{3}$ Department of Infectious Diseases and Clinical Microbiology, Ahi Evran University School of Medicine, Kirsehir, Turkey \\ * Corresponding author: Fikriye Milletli-Sezgin E-mail: fikriye.sezgin@ahievran.edu.tr ORCID: 0000-0002-8317-2312 \\ Received: 29 December 2018 Accepted: 18 May 2019
}

\begin{abstract}
Aim: To evaluate the relationship between dynamic thiol-disulfide homeostasis which is a novel oxidative stress marker and levels of HBV DNA, and the oxidant-antioxidant balance.

Material and Method: In the controlled study which included chronic hepatitis B (CHB) patients and healthy volunteers, dynamic Thiol-disulphide homeostasis (TDH) was measured using a novel automated method developed by Erel. Disulfide / total thiol (\%), disulfide / native thiol (\%), and native thiol / total thiol (\%) rates were calculated using the previously determined concentrations of disulfides, native thiols, and total thiols.

Results: Of thiol / disulfide homeostasis parameters, native thiol, total thiol, and disulfide levels were statistically lower in the CHB patient group $(p<0.05)$. As a result of the correlation analyses, a significant negative correlation was determined between HBV DNA levels and disulfide / native thiol, disulfide / total thiol, and native thiol / total thiol parameters ( $p<0.05$ ).

Conclusions: Our results suggest that oxidative stress increases with the rise in HBV-DNA levels and that the antioxidant defense may have weakened.
\end{abstract}

Keywords: chronic hepatitis B, thiol-disulfide homeostasis, HBV-DNA

() 2019 by the authors; licensee MEDITAGEM Ltd., Turkey. This article is an open access article distributed under the terms and conditions of the Creative Commons Attribution License (http://creativecommons.org/licenses/by/4.0/). 


\section{ÖZ}

Amaç: HBV DNA seviyeleri ile yeni bir oksidatif stres belirteci olan dinamik tiyol-disülfit homeostazı ve oksidan-antioksidan dengesi arasındaki ilişkiyi değerlendirmektir.

Gereç ve Yöntem: Kronik hepatit B (KHB) hastalarını ve sağlıklı gönüllüleri içeren kontrollü çalışmada, dinamik Tiyol-disülfid hemostazı (TDH), Erel tarafından geliştirilen yeni bir otomatik yöntem kullanılarak ölçüldü. Disülfid / total tiyol (\%), disülfid / nativ tiyol (\%) ve nativ tiyol / total tiyol (\%) oranları, önceden belirlenmiş disülfid konsantrasyonları, nativ tiyoller ve total tiyoller kullanılarak hesaplandı.

Bulgular: Tiyol / disülfit homeostazı parametrelerinde, nativ tiyol, total tiyol ve disülfit seviyeleri KHB hasta grubunda istatistiksel olarak düşüktü ( $p<0.05$ ). Korelasyon analizleri sonucunda HBV DNA düzeyleri ve disülfit / nativ tiyol, disülfit / total tiyol ve nativ tiyol / total tiyol parametreleri arasında anlamlı bir negatif korelasyon tespit edildi $(p<0.05)$.

Sonuç: Sonuçlarımız oksidatif stresin HBV-DNA seviyelerinin yükselmesiyle arttığını ve antioksidan savunmanın zayıflamış olabileceğini göstermektedir.

Anahtar kelimeler: kronik hepatit B, tiyol-disülfid hemostazı, HBV-DNA

\section{INTRODUCTION}

It is known that approximately two billion people in the world have encountered hepatitis B virus (HBV), and approximately 400 million people have chronic hepatitis $B$ (CHB). Every year approximately 600,000 people are estimated to have lost their lives due to HBV infection and/or associated complications [1, 2]. The natural course of the $\mathrm{HBV}$ infection is quite variable and is clinically well defined, however, the mechanisms underlying the pathogenesis of the disease have not been fully understood. The development of the body's immune system, strength of the immune response, and properties of the virus are the most important factors determining the natural course [3]. A diagnosis of $\mathrm{CHB}$ is dependent on positive $\mathrm{HBsAg}$ findings for longer than a period of 6 months. Additionally, $\mathrm{HBeAg}$ and HBV DNA levels are monitored in order to evaluate HBV replication [4].

A balance exists in the oxidation-reduction systems within each cell in our bodies that is essential for the survival of the cells. If this balance is disturbed, either oxidant levels increase or antioxidant levels decrease; and this is defined as "oxidative stress." This condition causes significant damage to various macromolecules in the cell such as the DNA, proteins, and lipids. Today, it is thought that oxidative stress has a major role in the pathogenesis of a wide range of diseases [5-7]. It was demonstrated that in contagious diseases, various inflammatory cells were activated and reactive oxygen species (ROS) fought against intra- and extracellular microbes [8]. This, in turn, causes an increase in the potential antioxidant capacity and in the production of free radicals $[9,10]$. Thiols are organic compounds that consist of the sulfhydryl (-SH) group with a key role in coordinating with the antioxidant defense network [11]. Oxidants lead thiols to undergo an oxidation reaction and form disulfide (RSSR) bonds [12]. In the case of oxidative stress, cystein residues are oxidized and reversible mixed disulfides form between low-molecular-weight thiols and protein thiol groups. Disulfide bonds may be reduced to thiol groups and thiol reserves increase again. By means of these reactions at the cellular level, dynamic thiol / disulfide homeostasis is maintained [13]. Intra- and extracellular thiols make up the total thiols; they are made of free or unreduced glutathione or are bound to blood proteins which are mostly albumins. While total thiol includes both reduced and oxidized thiols, native thiol reflects only reduced thiols (SH). Dynamic thiol / disulfide homeostasis plays an important role in antioxidant defenses, detoxification, cell signaling, transcription, apoptosis, and the regulation of enzymatic activity [14].

As a novel oxidative stress indicator, thiol disulfide homeostasis parameters have been investigated in relation to the pathogeneses of various diseases such as cardiovascular diseases [15], diabetes mellitus [16], chronic kidney failure [17], autoimmune diseases [18], cancer [19], Alzheimer's disease [20]. Investigating the dynamic thiol / disulfide homeostasis activity in CHB patients may facilitate the understanding of the role of the redox state in this infection. By means of a novel method developed by Erel et al. [21] in 2014, the measurement of dynamic thiol / disulfide homeostasis has begun to be performed with high accuracy and sensitivity with an easy and repeatable technique. Our 
Table 1. HBV DNA levels, positive HBeAg and ALT levels of the study groups

\begin{tabular}{|c|c|c|c|}
\hline & $\begin{array}{c}\text { HBV DNA IU/ml } \\
\text { (n=132) }\end{array}$ & $\begin{array}{c}\text { HBe Ag Positive } \\
\text { (n=24) }\end{array}$ & ALT (IU/L) \\
\hline Group 1 & $<6(33)$ & 1 & $26.18 \pm 11.9$ \\
\hline Group 2 & $6-10^{3}(42)$ & - & $26.19 \pm 16.5$ \\
\hline Group 3 & $10^{3}-10^{6}(36)$ & 5 & $26.37 \pm 14.9$ \\
\hline Group 4 & $>10^{6}(21)$ & 18 & $63 \pm 49.6$ \\
\hline
\end{tabular}

aim in this study is to identify using a novel automated method the levels of native thiols, total thiols, and disulfides, and the rates of disulfide/native thiol, disulfide/total thiol, and native thiol/total thiol, which determine dynamic thiol / disulfide homeostasis in CHB patients and investigate their relationships with HBV DNA levels.

\section{MATERIALS AND METHODS}

\section{Study Design}

This study was carried out in accordance with the Declaration of Helsinki Guidelines for Good Clinical Practice and was approved by the Local Ethical Committee of the Ahi Evran University Medical Faculty (2017-12/117). Informed voluntary consent forms were obtained from all individuals who participated in the study. 132 patients who were followed up previously at Kirsehir Ahi Evran University Education and Research Hospital Infectious Diseases Outpatient Clinic for a diagnosis of $\mathrm{CHB}$ were included in the study. The study group is constituted by 4 groups based on HBV DNA levels. The HBeAg, ALT, and HBV DNA levels of the groups have been presented in Table 1. The control group consists of 42 healthy volunteers who had no chronic diseases and tested negative for serological markers of hepatitis $B$.

\section{The Collection of Samples and Measurement of Thiol / disulfide Homeostasis Test Levels}

The collected blood samples were centrifuged for 10 minutes at $1500 \mathrm{rpm}$ to obtain serum. Serological markers of hepatitis were analyzed by the method of chemiluminescence enzyme immunoassay test (Roche Modular Analytics, E-601; Roche Diagnostics, Germany). HBV DNA levels were determined by real time polymerase chain reaction (PCR) with an automated system (ROCHE / COBAS ${ }^{\circledR}$ TaqMan ${ }^{\circledR}$ System). The serums were preserved in $-80^{\circ} \mathrm{C}$ to be analyzed later with thiol / disulfide homeostasis tests. Thiol / disulfide homeostasis test levels were measured using a fully automated and spectrophotometric method recently developed by Erel and Neselioglu [15]. After the native and total thiols were determined, disulfide concentration was determined based on the formula below:
Table 2. Demographic features and laboratory findings of the study population of Hepatitis B patients and control groups

\begin{tabular}{|c|c|c|c|}
\hline Variables & Patient $(\mathbf{n}=132)$ & Control $(\mathbf{n}=\mathbf{4 2})$ & $\boldsymbol{p}$ value \\
\hline Age (years) & $43.1 \pm 11.7$ & $41.3 \pm 15.6$ & 0.306 \\
\hline Gender $(\mathrm{M} / \mathrm{F})$ & $74 / 58$ & $19 / 23$ & 0.137 \\
\hline ALT $(\mathrm{IU} / \mathrm{L})$ & $32.1 \pm 27.2$ & $23.8 \pm 6.4$ & $0.001^{*}$ \\
\hline Native Thiol $(\mu \mathrm{mol} / \mathrm{L})$ & $286.0 \pm 62.8$ & $376.5 \pm 86.9$ & $<0.001^{*}$ \\
\hline Total Thiol $(\mu \mathrm{mol} / \mathrm{L})$ & $421.7 \pm 89.2$ & $555.9 \pm 125.1$ & $<0.001^{*}$ \\
\hline Disulphide $(\mu \mathrm{mol} / \mathrm{L})$ & $67.9 \pm 14.2$ & $89.7 \pm 19.4$ & $<0.001^{*}$ \\
\hline Disulphide /Native Thiol $(\%)$ & $23.9 \pm 2.5$ & $23.9 \pm 1.3$ & 0.138 \\
\hline Disulphide /Total Thiol $(\%)$ & $16.1 \pm 1.1$ & $16.1 \pm 0.6$ & 0.137 \\
\hline Native Thiol/Total Thiol $(\%)$ & $67.7 \pm 2.2$ & $67.6 \pm 1.2$ & 0.140 \\
\hline
\end{tabular}

\section{Disulfide $=($ total thiol-native thiol $) / 2$}

Disulfide / total thiol (\%), disulfide / native thiol (\%), and native thiol / total thiol (\%) rates were calculated using the previously determined concentrations of disulfide, native thiol, and total thiol.

\section{Statistical Analysis}

Analyses were performed using SPSS software (version 16.0, SPSS, Chicago, IL). The Kolmogorov-Smirnov test was used to evaluate the normality of the distributions of variables. Parametric data were expressed as the mean \pm standard deviation (SD). Student's t-test was used to compare numerical variables with normal distribution. One-way analysis of variance was utilised to compare more than two groups. Pearson correlation tests were used to determine relationship between variables. $P$ values $<0.05$ were considered statistically significant.

\section{RESULTS}

74 of the 132 total patients of CHB were male and 58 were female, and their mean age was $43.1 \pm 11.7$ years. 19 in the control group were male and 23 were female, and their mean age was $41.3 \pm 15.6$ years. There was no significant difference between the patient and the control groups in terms of age and sex ( $p>0.05)$. The range of ALT levels in the CHB patient group was between 6 and $172 \mathrm{IU} / \mathrm{L}$ and 26 (19.6\%) patients had high ALT levels (>40 IU/L). ALT levels were statistically higher in the patient group compared to the control group ( $p<0.05$, Table 2). 24 (18.2\%) of the CHB patients were detected positive for $\mathrm{HBeAg}$; only 1 of these patients had a HBV DNA level of $<6$ while the rest had HBV DNA levels $>10^{4}$.

Of thiol / disulfide homeostasis parameters, native thiol, total thiol, disulfide levels were statistically lower in the CHB patient group $(p<0.05) \quad($ Table 2$)$. The demographic attributes and laboratory findings of the study population based on HBV DNA levels have been demonstrated in detail in Table 3. The analysis investigating the correlation 
Table 3. The correlation coefficients between HBV DNA titers of the patients and thiol/disulphide homeostasis parameters

\begin{tabular}{|c|c|c|}
\hline Variables & r & p value \\
\hline Native Thiol $(\mu \mathrm{mol} / \mathrm{L})$ & 0.111 & 0.207 \\
\hline Total Thiol $(\mu \mathrm{mol} / \mathrm{L})$ & 0.070 & 0.428 \\
\hline Disulphide $(\mu \mathrm{mol} / \mathrm{L})$ & -0.030 & 0.734 \\
\hline Disulphide $/$ Native Thiol $(\%)$ & -0.294 & $0.001^{*}$ \\
\hline Disulphide /Total Thiol $(\%)$ & -0.294 & $0.001^{*}$ \\
\hline Native Thiol/Total Thiol $(\%)$ & 0.294 & $0.001^{*}$ \\
\hline
\end{tabular}

Table 4. Demographic features and laboratory findings of the Hepatitis B patients grouped by HBV DNA levels

\begin{tabular}{|c|c|c|c|c|c|}
\hline Variable & $\begin{array}{l}\text { Group } 1 \\
(n=33)\end{array}$ & $\begin{array}{l}\text { Group 2 } \\
(n=40)\end{array}$ & $\begin{array}{l}\text { Group } 3 \\
(n=38)\end{array}$ & $\begin{array}{l}\text { Group } 4 \\
(n=21)\end{array}$ & $p$ value \\
\hline Age (years) & $46.6 \pm 10.4$ & $43.0 \pm 12.2$ & $40.4 \pm 12$ & $43.2 \pm 11.8$ & 0.175 \\
\hline Gender (M/F) & $21 / 12$ & $12 / 18$ & $20 / 18$ & $11 / 10$ & 0.787 \\
\hline HBV DNA & $<6$ & $\begin{array}{c}343.3 \pm \\
283.3\end{array}$ & $\begin{array}{c}28480 \pm \\
82911\end{array}$ & $\begin{array}{c}74330000 \pm \\
33170400\end{array}$ & $<0.001^{*}$ \\
\hline ALT (IU/L) & $29.2 \pm 15.8$ & $25.5 \pm 12.8$ & $32.2 \pm 24.6$ & $49.0 \pm 51.0$ & $0.011^{*}$ \\
\hline $\begin{array}{c}\text { Native Thiol } \\
(\mu \mathrm{mol} / \mathrm{L})\end{array}$ & $\begin{array}{c}276.5 \pm \\
57.5\end{array}$ & $\begin{array}{c}281.1 \pm \\
51.2\end{array}$ & $\begin{array}{c}300.8 \pm \\
79.3\end{array}$ & $\begin{array}{c}283.2 \pm \\
56.2\end{array}$ & 0.372 \\
\hline $\begin{array}{c}\text { Total Thiol } \\
(\mu \mathrm{mol} / \mathrm{L})\end{array}$ & $\begin{array}{c}411.5 \pm \\
79.1\end{array}$ & $\begin{array}{c}418.2 \pm \\
74.5\end{array}$ & $\begin{array}{c}439.6 \pm \\
113.7\end{array}$ & $\begin{array}{c}412.0 \pm \\
80.5\end{array}$ & 0.523 \\
\hline $\begin{array}{c}\text { Disulphide } \\
(\mu \mathrm{mol} / \mathrm{L})\end{array}$ & $67.5 \pm 11.7$ & $68.5 \pm 13.3$ & $69.4 \pm 17.7$ & $64.4 \pm 12.6$ & 0.617 \\
\hline $\begin{array}{c}\text { Disulphide } \\
\text { /Native Thiol (\%) }\end{array}$ & $24.8 \pm 2.8$ & $24.5 \pm 3.1$ & $23.2 \pm 1.7$ & $22.8 \pm 1.5$ & $0.005^{*}$ \\
\hline $\begin{array}{c}\text { Disulphide /Total } \\
\text { Thiol (\%) }\end{array}$ & $16.5 \pm 1.2$ & $16.4 \pm 1.3$ & $15.8 \pm 0.8$ & $15.6 \pm 0.7$ & $0.003^{*}$ \\
\hline $\begin{array}{c}\text { Native Thiol/Total } \\
\text { Thiol (\%) }\end{array}$ & $66.9 \pm 2.4$ & $67.2 \pm 2.6$ & $68.3 \pm 1.5$ & $68.7 \pm 1.4$ & $0.003^{*}$ \\
\hline
\end{tabular}

between the HBV DNA titres of the patients and their thiol/ disulfide homeostasis parameters has been presented comprehensively in Table 4. There was no significant correlation between HBV DNA levels and Native Thiol, Total Thiol, and Disulfide. The correlation analysis revealed significant positive correlation between HBV DNA levels and native thiol / total thiol (Figure 1, $\mathrm{p}<0.05$ ) and negative correlation with disulfide / native thiol, disulfide / total thiol parameters (Figures $\mathbf{2}$ and $\mathbf{3}, \mathrm{p}<0.05$ ).

\section{DISCUSSION}

Hepatitis B virus (HBV) infection is an important disease worldwide and the follow-up of these patients is important. Patients who have had a CHB diagnosis with positive $\mathrm{HBsAg}$ findings for longer than a period of 6 months may be at one of the different stages specified as immune tolerant, inactive hepatitis $B$ carrier, and reactivation depending on their levels of HBV DNA, HBeAg/antiHBeAg positivity, and levels of ALT [4]. Histopathological evaluation is the invasive method of diagnosis used to confirm a CHB diagnosis, however, it may not be performed on all patients due to coagulopathy and decompensation. Thus, the development of noninvasive tests for the diagnosis and follow-up of these patients is important.

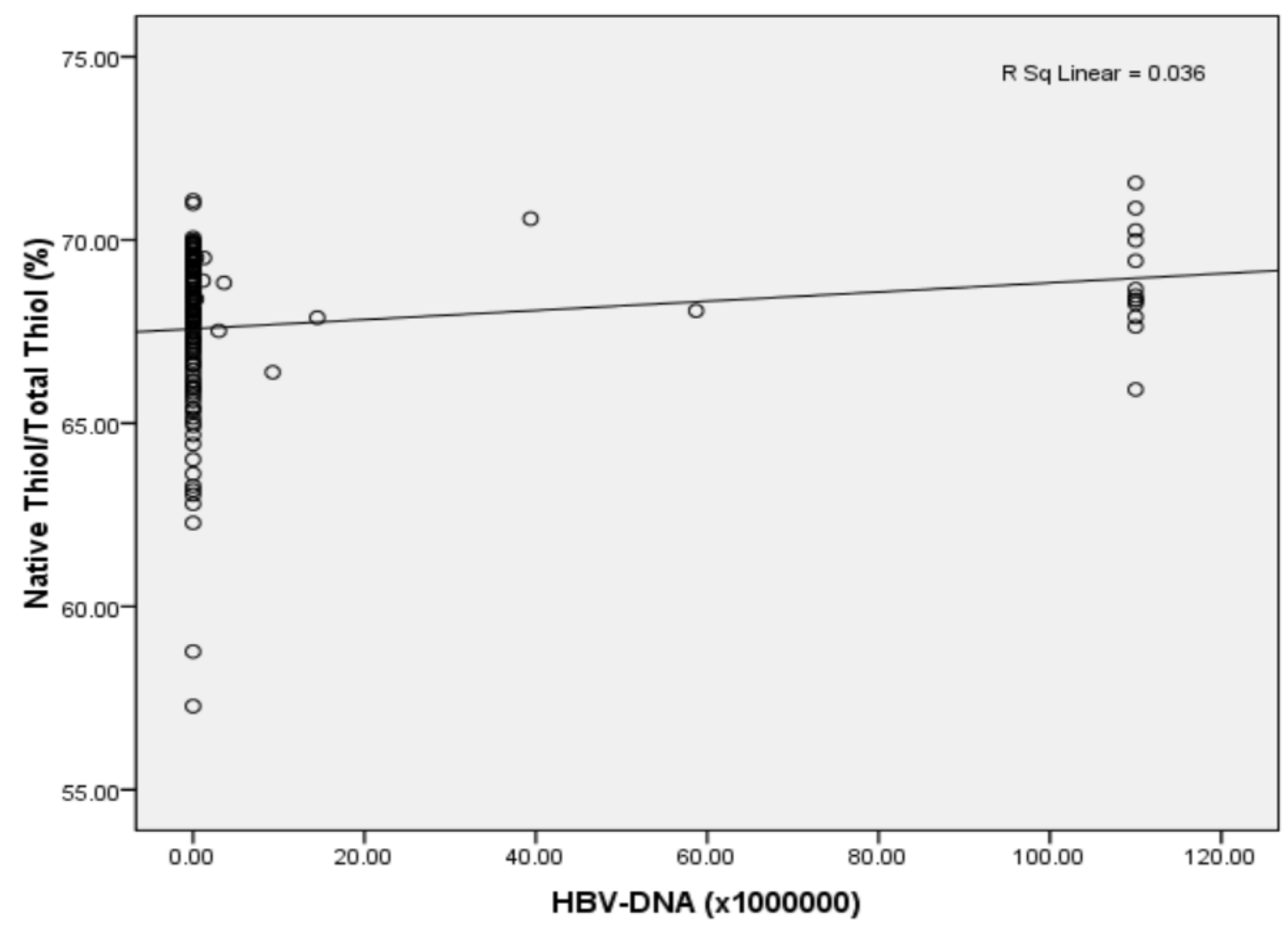

Figure 1. The relationship between serum Native Thiol/Total Thiol ratio (\%) and HBV-DNA $(r=0.294, p=0.001)$ 


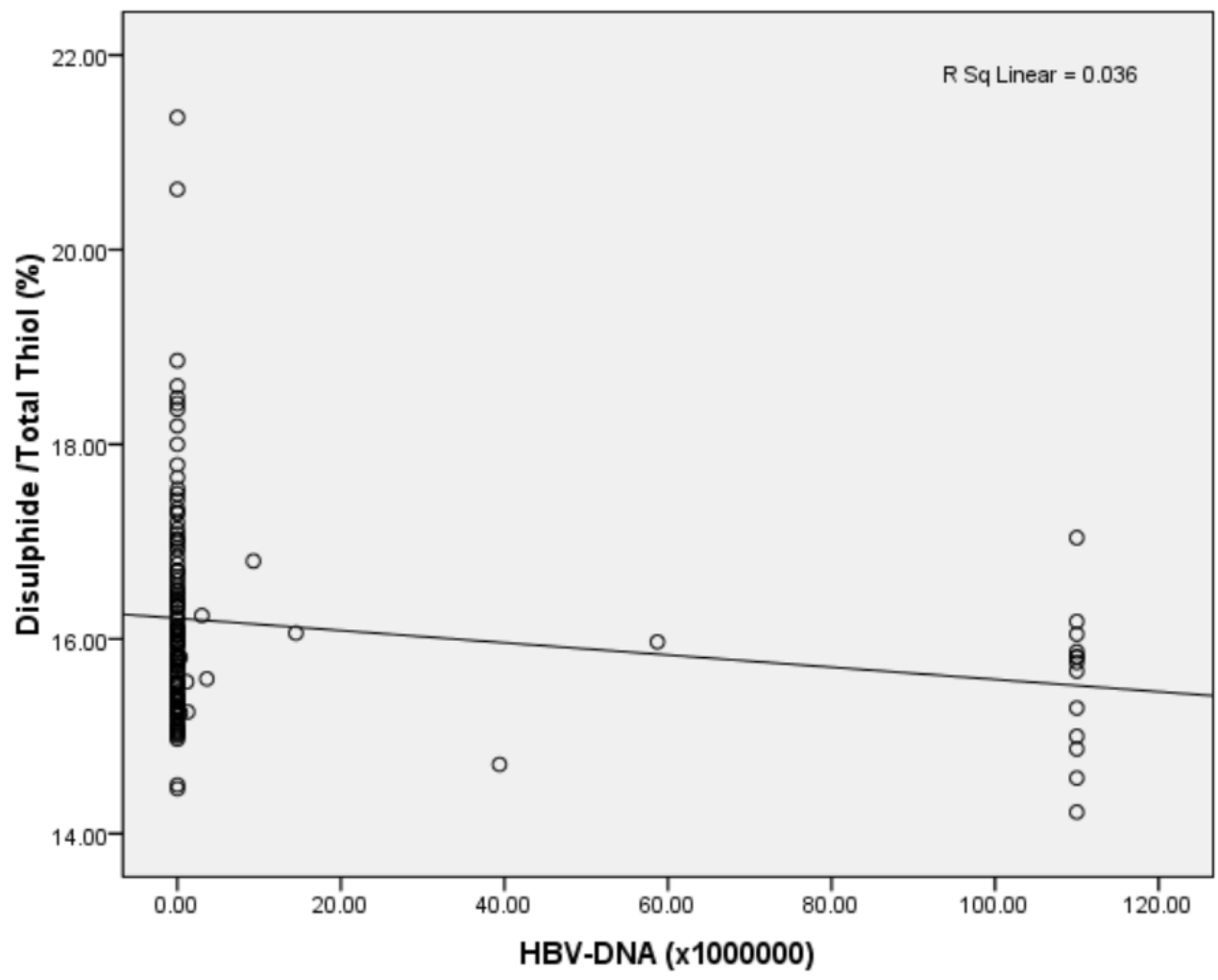

Figure 2. The relationship between serum Disulphide /Total Thiol ratio (\%) and HBV-DNA $(r=-0.294, p=0.001)$

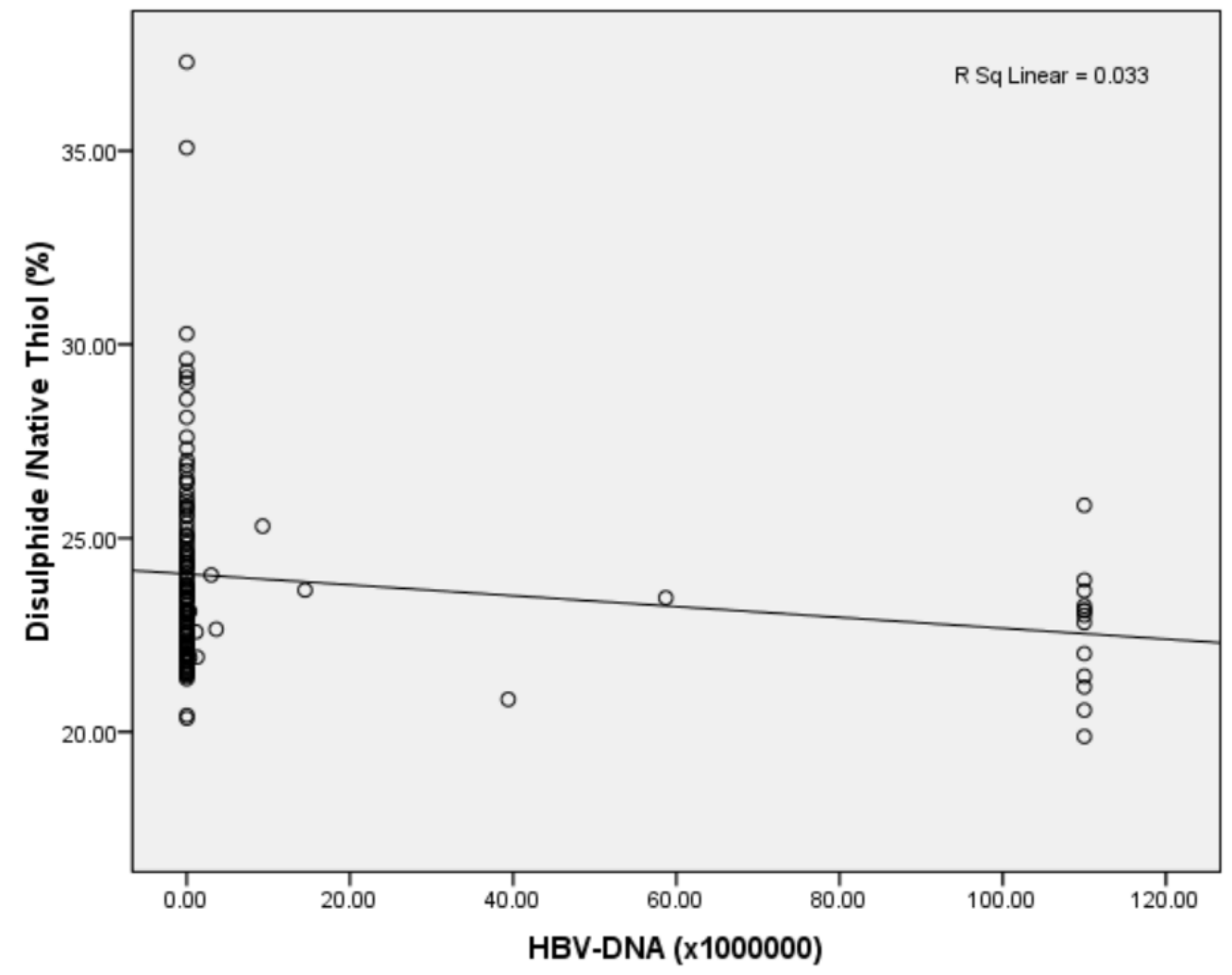

Figure 3. The relationship between serum Disulphide /Native Thiol ratio (\%) and HBV-DNA $(r=-0.294, p=0.001)$

Thiol-disulfide homeostasis is of vital importance. While only one side of this two-sided balance could be measured since 1979, with the new method developed by Erel and Neselioglu, the levels of both variables can now be measured separately or cumulatively and can be evaluated both individually and collectively. As far as we know, this study is the first that investigates the thiol / disulfide homeostasis balance in CHB patients with respect to HBV DNA levels and healthy controls. 
Studies exist that reveal oxidant-antioxidant imbalance in $\mathrm{CHB}$ patients and relate the oxidant-antioxidant state to the ethiopathogenesis and severity of CHB [22]. Various indicators of oxidative stress have been studied in various clinical forms of hepatitis B. In these studies, mostly malondialdehyde (MDA) was measured as the oxidation marker and was found to be significantly higher in patients with hepatitis B infection compared to healthy individuals. This marker was reported to show positive correlation with alanine aminotransferase (ALT), HBV-DNA [23], total and direct bilirubin and liver ultrasonography findings [24]. In another study, although a significant increase in the MDA levels of chronic hepatitis $B$ patients was determined, no significant difference was found between inactive $\mathrm{HBsAg}$ carriers and controls [25]. In a study they carried out, Severi et al. [26] revealed that even though HBV replication produced oxidative stress, it did not have a significant effect on lipid peroxidation (MDA levels).

Reactive oxygen species (ROS) are challenging to measure directly because of their instability. In related studies, Bhargava et al. [27] reported increased ROS levels in the lymphocytes of chronic hepatitis B patients. Wang, K. et al. [28], showed increased NO levels in CVHB. In another study, a significant increase in superoxide anion radicals was determined in patients with HBV-related HCC [29]. Literature reviews also reveal studies done with enzymes that are known to produce ROS (like myeloperoxidase, xanthine, oxidase). If we consider the extreme amounts of oxidation seen in Hepatitis B patients, probably very high levels of plasma MPO may foreshadow B. Impressively, the truth is the exact opposite. A negative correlation between HBV DNA levels and MPO was found in a study [30]. This unexpected correlation may be because the MPO measurement was done on the plasma and not on the hepatic tissue. In contrast to this study, Guler et al. [31] observed a significant increase in serum MPO levels in active and inactive hepatitis $B$ in comparison to healthy controls. They reported that MPO levels showed a positive correlation with HBV DNA and ALT levels.

Protein oxidation byproducts may provide valuable clues related to the source and severity of oxidative stress. Studies on protein oxidation are even fewer in number. Protein oxidation byproducts mostly include sulphur oxides, protein hydroxides, 3-nitrotyrosine, and carbonyl variants [32]. In a study done by Namiduru et al. [33], no significant difference was found between the plasma nitrotyrosine levels of healthy individuals and those of patients with chronic viral hepatitis B. In contrast, Meng et al. [34] demonstrated a significant increase in serum nitrotyrosine levels of patients with chronic hepatitis $B$. These results show that increased nitric oxide may not always be reflected in patients' plasmas or serums. On the other hand, Tasdelen et al. demonstrated in their study a weak to moderate level of correlation between HBV DNA and carbonyl levels, indicating that varying levels of oxidative stress is produced in hepatitis $B$ infection [30].

In this study, native thiol, total thiol and disulfide values of serum Thiol / disulfide hemostasis parameters were investigated in four groups of $\mathrm{CHB}$ patients we discriminated according to the increase of HBV DNA replication. As a result of our study, serum native thiol and total thiol levels were found to be significantly lower in $\mathrm{CHB}$ patients compared to the control group. Such low levels may be considered an indication of the inadequacy of antioxidant defences in CHB patients. Decreased thiol levels in $\mathrm{CHB}$ disease may cause the liver to become vulnerable to oxidative stress. When we compared the groups according to HBV DNA levels, revealed significant positive correlation between HBV DNA levels and native thiol / total thiol and negative correlation with disulfide / native thiol, disulfide / total thiol parameters. These results suggest that hemostasis is impaired according to the control group. The increase in $\mathrm{HBV}$ replication suggests that there is a decrease in antioxidant capacity even if oxidant indicators do not increase. Our results show that hemostasis is impaired and all parameters are decreased.

Disulfide level is expected to increase and thiol level decreases under oxidative stress. However, disulfide findings in our study were lower compared to healthy subjects. These findings may be explained with other factors affecting the thiol-disulfide balance besides oxidative stress such as; the rates of the thiol-disulfide exchange reactions, thiol oxidation by ROS and possible repair processes, enzymatic extracellular degradation of GSH and liver release of thiol-containing molecules $[35,36]$. Since proteins have unique functions, more attention must be paid to protein oxidation. The ability to measure the products of protein oxidation is important to bring to light the pathogenesis of the disease. However, since no methods exist that can determine protein oxidations and measure them individually, new methods must be developed.

\section{CONCLUSION}

This study, values indicating that the thiol / disulfide homeostasis balance is impaired in patients with chronic hepatitis have been determined. The monitoring of the thiol / disulfide homeostasis balance in clinical practice may not be useful method to evaluate the chronicity of hepatitis $B$. 
More longitudinal and prospective studies are needed to clarify the pathophysiological role of serum thiol / disulfide homeostasis balance in the progression of the disease.

\section{DECLARATION OF CONFLICT OF INTEREST}

The authors declare that there is no conflict of interest. This work was supported by Ahi Evran University Scientific Research Project Unit with TIP.A4.17.007 project number.

\section{REFERENCES}

1. Thomas D, Zoulim F. New challenges in viral hepatitis. Gut 2012;61:1-5.

2. World Health Organization. Prevention and Control of Viral Hepatitis Infection: Framework for Global Action. Geneva: WHO, 2012. http://apps.who.int/iris/bitstream/ handle/10665/130012/WHO_HSE_PED_HIP_GHP_2012. 1_eng.pdf;jsessionid=702912B1D626C665E81559E74B8 CAE49? sequence $=1$

3. Yapali S, Talaat N, Lok AS. Management of hepatitis B: our practice and how it relates to the guidelines. Clin Gastroenterol Hepatol 2014;12:16-26.

4. Lok AS. Serologic diagnosis of hepatitis B virus infection. Waltham, MA: UpToDate, Inc. http://www.uptodate.com /contents/serologic-diagnosis-of-hepatitis-bvirus-infecti on

5. Janssen-Heininger YM, Mossman BT, Heintz $\mathrm{NH}$, et al. Redox-based regulation of signal transduction: principles, pitfalls, and promises. Free Radic Biol Med 2008;45:1-17.

6. Thanan R, Oikawa S, Hiraku Y, et al. Oxidative Stress and Its Significant Roles in Neurodegenerative Diseases and Cancer. Int J Molecul Sci 2014;16:193-217.

7. Cai Z, Yan LJ. Protein Oxidative Modifications: Beneficial Roles in Disease and Health. J Biochem Pharmacol Re. 2013;1:15-26.

8. Esen R, Aslan M, Kucukoglu ME, et al. Serum paraoxonase activity, total thiols levels, and oxidative status in patients with acute brucellosis. Wien Klin Wochenschr 2015;127:427-33.

9. Dundaroz R, Erenberk U, Turel O, Demir AD, Ozkaya E, Erel O. Oxidative and antioxidative status of children with acute bronchiolitis. J Pediatr (Rio J) 2013;89:407-11.

10. Karsen $H$, Sunnetcioglu M, Ceylan RM, et al. Evaluation of oxidative status in patients with Fasciola hepatica infection. Afr Health Sci 2011;11:S14-8.
11. Sen CK, Packer L. Thiol homeostasis and supplements in physical exercise. Am J Clin Nutr 2000;72:653-69.

12. Cremers $\mathrm{CM}$, Jakob U. Oxidant sensing by reversible disulfide bond formation. J Biol Chem 2013;288:2648996.

13. Jones DP, Liang Y. Measuring the poise of thiol/disulfide couples in vivo. Free Radic Biol Med 2009;47:1329-38.

14. Biswas S, Chida AS, Rahman I. Redox modificationsof protein-thiols: emerging roles in cell signaling. Biochem Pharmacol 2006;71:551-64.

15. Altıparmak IH, Erkuş ME, Sezen $H$, et al. The relation of serum thiol levels and thiol/disulphide homeostasis with the severity of coronary artery disease. Kardiol Pol 2016;74:1346-53.

16. Ateş I, Kaplan $M$, Yüksel $M$, et al. Determination of thiol/disulphide homeostasis in type 1 diabetes mellitus and the factors associated with thiol oxidation. Endocrine 2016;51:47-51.

17. Himmelfarb, J., McMonagle, E. and McMenamin, E. Plasma Protein Thiol Oxidation and Carbonyl Formation in Chronic Renal Failure. Kidney International 2000;58:2571-2578.

18. Kaplan M, Ates I, Yuksel M, et al. Thiol/disulphide homeostasis in celiac disease. World J Gastrointest Pharmacol Ther 2017;8:120-26.

19. Hanikoglu F, Hanikoglu A, Kucuksayan E, et al. Dynamic thiol/disulphide homeostasis before and after radical prostatectomy in patients with prostate cancer. Free Radic Res 2016 Nov;50:79-84.

20. Gümüşyayla S, Vural G, Bektaş H, Deniz O, Neşelioğlu S, Erel O. A novel oxidative stress marker in patients with Alzheimer's disease: dynamic thiol-disulphide homeostasis. Acta Neuropsychiatr 2016;28:315-20.

21. Erel O, Neşelioğlu S. A novel and automated assay for thiol/disulphide homeostasis. Clin Biochem 2014;47:32632.

22. Alavian SM, Showraki A. Hepatitis B and its relationship with oxidative stress. Hepatitis monthly 2016;16:e37973.

23. Sen V, Uluca U, Ece A, et al. Serum prolidase activity and oxidant-antioxidant status in children with chronic hepatitis B virus infection. Ital J Pediatr 2014;40:95. 
24. Mahdy KA, Abd-El-Shaheed A, Khadr ME, El-Shamy KA. Antioxidant status and lipid peroxidation activity in evaluating hepatocellular damage in children. East Mediterr Health J 2009;15:842-52.

25. Duygu F, Karsen H, Aksoy N, Taskin A. Relationship of oxidative stress in hepatitis $B$ infection activity with HBV DNA and fibrosis. Ann Lab Med 2012;32:113-18.

26. Severi T, Ying C, Vermeesch JR, et al. Hepatitis B virus replication causes oxidative stress in HepAD38 liver cells. Mol Cell Biochem 2006;290:79-85.

27. Bhargava A, Khan S, Panwar $H$, et al. Occult hepatitis $B$ virus infection with low viremiainduces DNA damage, apoptosis and oxidative stress in peripheral blood lymphocytes. Virus Res 2010;153:143-50.

28. Wang K, Han L, Lu Q,Wang B, Li X,Wang H. Nitric oxide and nitric oxide synthase in patients with chronic hepatitis B. Zhonghua shi yan he lin chuang bing du xue za zhi= Zhonghua shiyan he linchuang bingduxue zazhi. Chinese J Experiment Clin Virol 2005;19:142-45.

29. Tsai SM, Lin SK, Lee KT, et al. Evaluation of redox statuses in patients with hepatitis $B$ virus-associated hepatocellular carcinoma. Ann Clin Biochem 2009;46:394-400.
30. Tasdelen Fisgin N, Aydin BK, Sarikaya H, et al. Oxidative stress and antioxidant defense in patients with chronic hepatitis B. Clin Lab 2012;58:273-80.

31. Guler SA, Tolun FI, Ucmak H, Haskaya G, Yavuz M, Yavuz M. Relationship between antioxidant capacity and oxidative stress in patients with chronic hepatitis B. Advance Laboratory Med Int 2014;4:17-25.

32. Dalle-Donne I, Giustarini D, Colombo R, Rossi R, Milzani A. Protein carbonylation in human diseases. Trends Mol Med 2003;9:169-76.

33. Namiduru ES, Namiduru M, Tarakcioglu M, Tanriverdi M. Levels of malondialdehyde, myeloperoxidase and nitrotyrosine in patients with chronic viral hepatitis $B$ and C. Adv Clin Exp Med 2012;21:47-53.

34. Meng LZ, Gao AW, Bian JF, Han LJ, Chen H. Study on Correlation between Oxidation-antioxidation and Chronic Hepatitis Viral B. Occupation Health, 2010;23.

35. Turell L, Radi R, Alvarez B. The thiol pool in human plasma: the central contribution of albumin to redox processes. Free Radic Biol Med 2013;65:244-53.

36. Dirican N, Dirican A, Sen O, et al. Thiol/disulfide homeostasis: A prognostic biomarker for patients with advanced non-small cell lung cancer? Redox Rep. 2016 Sep;21:197-203. 